\title{
Special issue on urbanization of irrigation systems
}

\author{
Robert S. Gooch
}

Published online: 16 September 2009

(C) Springer Science + Business Media B.V. 2009

Urbanization of irrigation systems occurs when the land served by those systems changes in nature from agricultural to urban, from farms to cities. The world has been on a general trend of urbanization for many years and has now reached the point where more than half of the world's population resides in urban areas. As cities expand, nearby agricultural lands are often the first to be developed.

The agencies that operate irrigation systems typically deliver water to multiple farms. When urbanization begins in the irrigation service area, a delivery agency must maintain the irrigation system in order to deliver water to the remaining farms, which often times wind through heavily urbanized areas to get to the delivery points. This results in increasing pressures on water rights and land rights, more regulation, and changes in operations and maintenance procedures, facility design, public relations and every other aspect of the irrigation delivery business. In addition, the business is likely to expand to include deliveries for urban use, such as potable water or urban landscape irrigation. Several agencies, including Oakdale and South San Joaquin Irrigation Districts in California, Black Mountain Irrigation District in Washington, and Westbank Irrigation District in British Columbia, have elected to build and operate their own potable water treatment plants and deliver the water to their urban landowners, a dramatic change in their core business.

The Salt River Project Water Users Association (SRVWUA) is an example of an irrigation agency that is close to completing the transition from agriculture to urban. This irrigation water provider currently delivers water to 250,000 acres in heart of what is now metropolitan Phoenix, Arizona. The SRVWUA was established in 1903 and its land remained in agriculture for the most part until the late 1940's. The development of low-cost residential air-cooling equipment, and the discovery of central Arizona as a desirable place to live, largely by military servicemen who were trained in the area during World War II, combined to set off a population boom in the Phoenix metropolitan area that continues to this day. In 1950, approximately $87 \%$ of the service area was agricultural land. Today it is only about $8 \%$. One of the articles in this journal describes the process and challenges faced by the SRVWUA.

R. S. Gooch $(\bowtie)$

Salt River Project, Phoenix, AZ, USA

e-mail: rsgooch@srpnet.com 
Other articles in this special edition include the effects of urbanization civil works design and construction, water rights and rights transfers, water resource management, and alternative water sources. Although this is far from a complete list of issues affecting urbanizing irrigation systems, it does provide real-world examples from which we can learn. And even though the examples in this special issue are drawn from only a handful of irrigation agencies in the Western United States, irrigation managers worldwide are, or soon will be, confronting similar issues.

This special issue contains expanded and peer reviewed versions of selected papers presented at the USCID Conference on Urbanization of Irrigated Land and Water Transfers held in Scottsdale, Arizona, in May 2008. Complete conference proceedings can be ordered through the USCID website, www.uscid.org.

Robert S. Gooch

Guest Editor

Salt River Project

Phoenix, Arizona USA 